\title{
Vegetation Structure and Temperature Regimes of Tropical Alpine Treelines
}

\author{
Maaike Y. Bader*t \\ Max Rietkerk† and \\ Arnold K. Bregt* \\ *Centre for Geo-information, \\ Wageningen University, P.O. Box 47, \\ 6700 AA Wageningen, The Netherlands \\ $\dagger$ Department of Environmental \\ Sciences, Copernicus Institute, Utrecht \\ University, P.O. Box 80115, 3508 TC \\ Utrecht, The Netherlands \\ \$Corresponding author. Address for \\ correspondence: University of \\ Oldenburg, Institute of Biology and \\ Environmental Sciences, Functional \\ Ecology of Plants, P.O. Box 2503, 26111 \\ Oldenburg, Germany \\ maaike.bader@uni-oldenburg.de
}

\begin{abstract}
Alpine treeline ecotones can be gradual transitions, abrupt boundaries, or patchy mosaics, and these different patterns may indicate important processes and dynamic properties. We present observed spatial patterns of a wide range of tropical treelines and try to explain these patterns. Treelines were studied at seven sites in the tropical and subtropical Andes (Argentina, Bolivia, Ecuador, and Venezuela) and on a Hawaiian volcano (Haleakala, Maui). Treeline vegetation structure was described using transects perpendicular to the treeline, and air and soil temperatures were measured above and below the forest boundary. Temperature fluctuations were much larger and the average temperature was higher in alpine vegetation than in forest. Most treelines were abrupt, with surprisingly similar patterns across a wide geographical range. This abruptness could result from positive feedback processes mediated by the differences in microclimate between forest and páramo. Our data is not conclusive about the relative importance of microclimate as opposed to fire in mediating such feedbacks. However, our extensive set of comparable data from different sites in a large geographical region is an important step toward a better understanding of the nature and dynamics of tropical alpine treelines.
\end{abstract}

\section{Introduction}

The transition between upper montane forest and low-stature alpine vegetation is a conspicuous landscape element on mountains worldwide. These alpine treelines have been the subject of scientific investigation for well over a century (Bühler, 1897/1898; Weberbauer, 1911). With the current concern about climatic change, alpine treelines have attracted attention as potential indicators of vegetation response to changes in temperature and precipitation (Noble, 1993; Kupfer and Cairns, 1996; Didier and Brun, 1998; Kullman, 1998; Kimball and Weihrauch, 2000), or at least as ecotones that are likely to be affected (Grace et al., 2002). However, the controls of treeline dynamics are still poorly understood (Tranquillini, 1979; Körner, 1998; Grace et al., 2002; Smith et al., 2003; Handa et al., 2005; Körner and Hoch, 2006). Therefore detailed predictions about the effects of global warming cannot be made (Malanson, 2001; Graumlich et al., 2004). This is true not only for the relatively well-studied alpine treelines in temperate regions, but even more so for those in the tropics.

Tropical alpine treelines differ from temperate alpine treelines mainly because they lack snow and have strong diurnal and weak annual temperature fluctuations (Monasterio, 1980; Smith and Young, 1987). Treeline forests in the wet tropics are usually cloud forests; a stunted, mossy and perpetually moist forest type (Hamilton et al., 1995). The tropical alpine vegetation most often consists of tussock grasses, although microphyllous shrubs are also common and may form shrublands. These alpine areas are often used for livestock grazing, combined with periodical burning of the vegetation. In the mesic northern Andes these alpine vegetation types are called páramo, which is the term we adopt for the alpine vegetation of all our study areas (see Table 1 for a distinction between páramo types and e.g. Smith and Young, 1987; Hofstede et al., 2003, for a discussion about tropical alpine vegetation types and names).
In this paper we use the term 'treeline' to denote the actual upper boundary of contiguous closed-canopy forest, irrespective of whether or not this represents the potential climatic upper limit for tree growth. Depending on the scale of observation, this boundary can be considered as a line or an ecotone of varying width.

Treelines have different spatial patterns in different parts of the world, including wide ecotones, mosaics of patches, and abrupt boundaries (Wardle, 1965; Miehe and Miehe, 1994; Malanson, 1997; Körner, 1998; Cairns and Waldron, 2003). These patterns may reveal underlying processes and may therefore help us to predict vegetation response to environmental changes (Armand, 1992; Wiegand et al., 2006). However, these underlying processes of the different patterns are not yet well understood.

A variety of hypotheses has been brought forward to explain specific treeline patterns. For instance, a transition from forest to scattered trees, as found at some coniferous treelines (Lauer, 1978; Stützer, 2000), can be explained by competition between trees (Tranquillini, 1979) or other negative neighbor interactions, e.g. shading causing a colder root-zone (Körner, 1998). In contrast, clustering of trees into patches or a closed forest can be explained by positive neighbor interactions (Tranquillini, 1979; Wilson and Agnew, 1992; Smith et al., 2003). The typical patches of upright trees or 'krummholz' (stunted and deformed trees), as well as forest 'fingers' extending up from the closed forest, at windy temperate treelines have been attributed to the sheltering effect of established trees (Smith et al., 2003; Alftine and Malanson, 2004; Bekker, 2005). Abrupt closed forest treelines are often attributed to fire, grazing, or other disturbances (Ellenberg, 1966; Norton and Schönenberger, 1984; Miehe and Miehe, 1994), but species interactions have also been proposed as an explanation for the abruptness of treelines (Wardle, 1965; Armand, 1992), in particular interactions through positive feedback between plant species and their environment (Armand, 1985; Wilson and Agnew, 1992). Additionally, abrupt treelines can emerge if seedling 


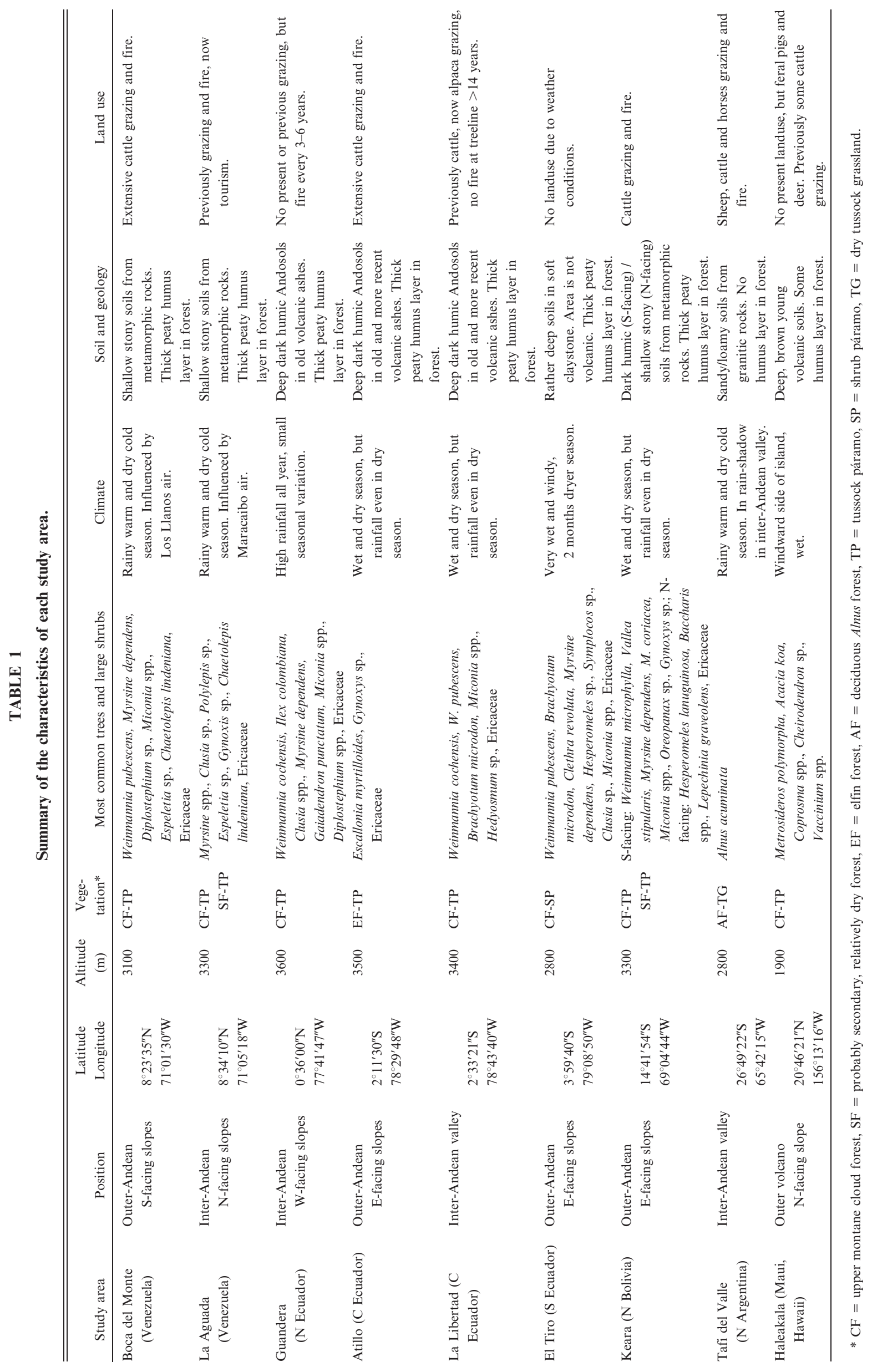


establishment decreases strongly with altitude while tree growth does not (Wiegand et al., 2006); such a situation may emerge due to species-specific demographic factors or again due to positive feedback (Bader, unpublished data).

Low temperature is probably an important determinant of treeline position, but it is not clear how temperature limits tree establishment or growth (Tranquillini, 1979; Körner, 1998). Questions that remain are whether soil or air temperature is most important, whether average or extreme temperatures or temperature sums are most important, and whether carbon gain, carbon use, or regeneration processes are most limiting (Körner, 1998; Hoch and Körner, 2003; Körner and Hoch, 2006; Piper et al., 2006). A worldwide survey of soil temperatures at treeline (Körner and Paulsen, 2004) revealed that most treelines had average growing season soil temperatures around $7^{\circ} \mathrm{C}$, while the three tropical treelines included in the survey had lower temperatures, around $5^{\circ} \mathrm{C}$. Average temperatures at treeline are generally higher outside than inside the forest (Azócar and Monasterio, 1980; Bendix and Rafiqpoor, 2001; Körner and Paulsen, 2004), which appears to present a paradox, because it would imply that the conditions for tree growth are better above treeline than below. However, a seasonal or even daily average temperature is unlikely to control physiological processes. Daily temperature extremes probably have a much more pronounced direct effect on plant performance and hence treeline patterning and dynamics, especially in the tropical alpine zone (Cavieres et al., 2000).

Wardle (1965; Wardle et al., 2001) has presented comparative studies of treelines and their patterns in different parts of the world, and Miehe and Miehe (1994, 2000) and Leuschner (1996) provide reviews of (sub-)tropical treelines. However, to date no comparison of quantified spatial patterns and their causes has been made between regions, with the exception of Armand (1992), who compared the floristic abruptness of two Russian treelines. In this paper we present observed spatial patterns of a range of tropical treelines, as well as air and soil temperature data from below and above these treelines, in order to contribute to a better understanding of patterns in a large geographical region.

\section{Methods}

\section{STUDY AREA}

Treelines were selected in a wide range of geographical locations, with the purpose of including most of the variation in tropical treeline types. The location of sites is depicted in Figure 1. General descriptions of the study areas can be found in Table 1. Most study areas are located in the mesic tropical Andes, with the exception of Tafi del Valle, which lies in a seasonally dry subtropical valley in northern Argentina, and Haleakala, on the tropical oceanic island of Maui (Hawaii).

\section{TREELINE STRUCTURE}

Treelines were described using representative transects perpendicular to the forest boundary, with sample points every $2 \mathrm{~m}$. At each sample point the vertical structure and composition of the vegetation was described, with a record of species presence in intervals of $25 \mathrm{~cm}$ along a vertical axis. At each sample point we also registered the altitude relative to a reference altitude.

The length of each transect depended on the nature of the forest boundary and the variation in vegetation cover. Transects were relatively short ( 40 to $50 \mathrm{~m}$ ) if boundaries were abrupt and páramo and forest were relatively homogeneous. More gradual boundaries and heterogeneous vegetation on either side required

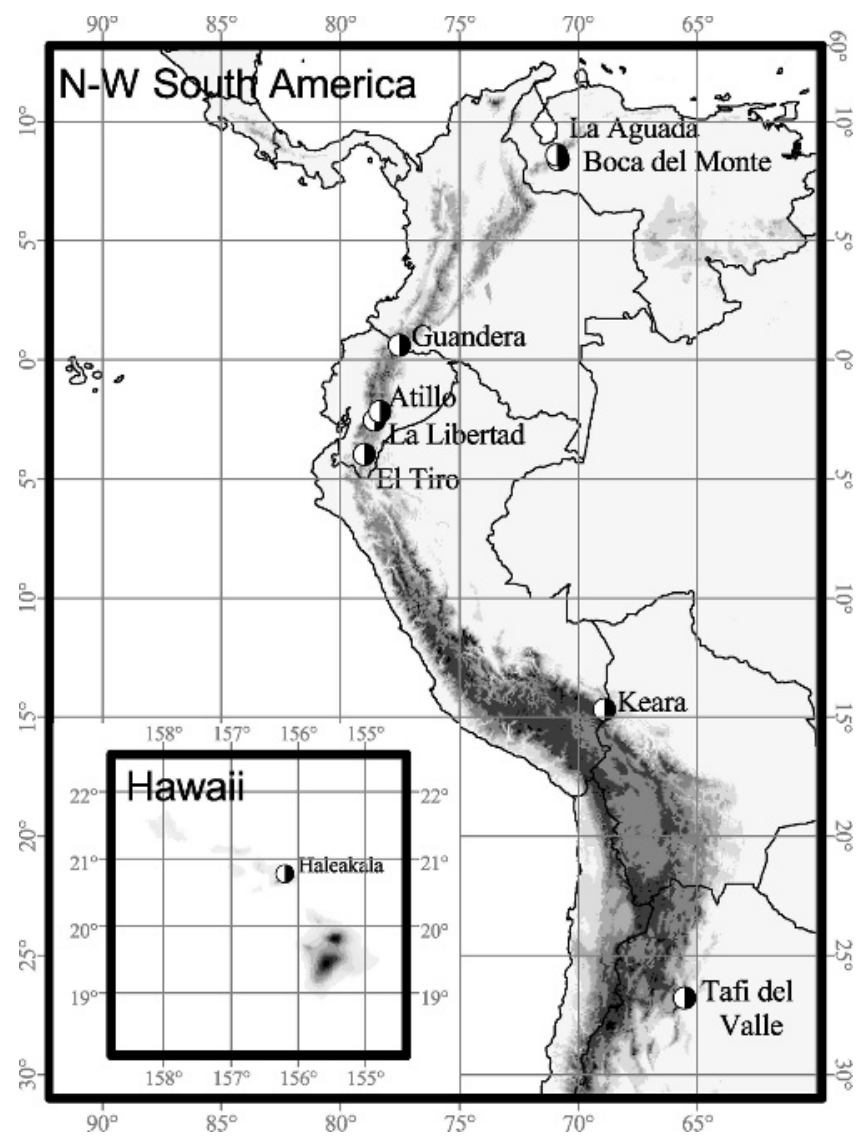

FIGURE 1. Map showing location of the study areas. Elevation data: GTOPO30, U.S. Geological Survey, 1996.

longer transects (up to $80 \mathrm{~m}$ ). A total number of 50 transects was sampled, divided over seven study areas.

Several methods were tested to characterize vegetation boundaries with our data, using different variables and quantitative methods. First we tested whether we could characterize the boundaries based on vegetation height alone, or whether we needed to use species composition as an additional parameter. The species composition was summarized as the first axis from a principal component analysis (PCA), performed per study area, including all species. This axis represented only 14 to $39 \%$ of the variation in the species composition, but it corresponded with the distinction between páramo and forest in all areas. Along the transects, changes in vegetation height co-occurred with changes in species composition, so the spatial patterns of the two parameters coincided strongly. Correlation coefficients (Spearman's rho) of vegetation height with the first PCA axis ranged from 0.63 to 0.86 ( $p<0.01$ in all cases $)$ in the different study areas. Because of the coincidence of patterns and these strong correlations, we could characterize the boundaries based on vegetation height alone, which is the simplest parameter and therefore preferred.

We then tested several quantitative boundary detection methods based on changes in vegetation height along transects. Such methods have been successfully used for detecting boundary locations (Ludwig and Cornelius, 1987; Johnston et al., 1992; Fortin, 1994; Camarero et al., 2000), and we assessed their usefulness to also characterize boundary shapes. The changes in vegetation height were quantified using windows of variance and moving split windows of different sizes ( 2 to $5+5$ cells) and with various difference metrics (variance, squared Euclidean distance, $t$ - 
TABLE 2

Frequency of treeline types in each study area, based on the abruptness of the change in vegetation height and in vegetation structure at the boundary (A-oh = abrupt and overhanging canopy, $A-f r=$ abrupt and fringed, $M=$ medium abrupt, $G=$ gradual, $P=$ patchy). Medium and gradual treelines are always fringed. Shading indicates treeline types that can be considered typical for each area.

\begin{tabular}{|c|c|c|c|c|c|c|}
\hline & A-oh & A-fr & M & G & $\mathrm{P}$ & total \\
\hline Boca del Monte & 0 & 6 & 2 & 1 & 0 & 9 \\
\hline Guandera & 5 & 7 & 0 & 0 & 0 & 12 \\
\hline La Libertad & 0 & 1 & 2 & 2 & 0 & 5 \\
\hline El Tiro & 0 & 0 & 2 & 1 & 0 & 3 \\
\hline Keara & 1 & 4 & 1 & 0 & 2 & 8 \\
\hline Tafi del Valle & 5 & 4 & 0 & 0 & 0 & 9 \\
\hline Haleakala & 0 & 0 & 0 & 0 & 4 & 4 \\
\hline total & 11 & 22 & 7 & 4 & 6 & 50 \\
\hline
\end{tabular}

test) (Ludwig and Cornelius, 1987; Johnston et al., 1992). The different methods and window sizes frequently resulted in different locations being pointed out as the boundary, and different boundary widths and shapes. Gaps in the forest canopy also caused confusion. In practice, the original plots of canopy height were always needed to clarify and validate what was seen in the plots of the changes.

We also tested a boundary description method based on curve fitting, assuming that the transition in vegetation height should show a sigmoidal pattern (Timoney et al., 1993; Cairns and Waldron, 2003). Although this method has previously been used for vegetation cover rather than height, we tested the applicability of the method for our data. We expected that the parameter that indicates the steepness of the function would differ according to the abruptness of the treeline. We used a logistic function, expressing vegetation height as a function of distance along the transect. Most treelines could be described by such a function $\left(R^{2}\right.$ $>0.5$ for $35 / 52$ transects). However, the steepness of the fitted function was affected more by gaps in the forest than by the abruptness of the actual treeline: forest gaps or highly irregular forest canopies lowered the steepness of the function as well as the $R^{2}$ values. The least steep functions, which also had the lowest $R^{2}$ values $(\leq 0.3)$, were found at treelines characterized by forest patches above the closed forest, where the height transition showed no sigmoidal pattern. This was a meaningful result, but in other cases forest gaps confused the signal of the actual páramoforest transition. Once again, the original plots of canopy height contained more information than the results of the curve fitting exercise.

Therefore, even though quantitative methods may work well for boundary detection and description for certain types of transitions and data, the treelines we studied could be characterized most efficiently using the most straightforward method of visually interpreting plots of the 'raw data.' We therefore classified the patterns visually using vegetation height and vertical structure as parameters. We arbitrarily set the minimum vegetation height for forest at $4 \mathrm{~m}$, and the maximum height for páramo at $1 \mathrm{~m}$. A change in vegetation height was considered "abrupt" if the transition from páramo to forest over $4 \mathrm{~m}$ high was $4 \mathrm{~m}$ long or less. It was considered "medium abrupt" if this transition was between 4 and $10 \mathrm{~m}$ long, and "gradual" if the transition was more than $10 \mathrm{~m}$ long. The class of "abrupt" transitions was subdivided in transitions with an overhanging tree canopy over páramo ("overhanging canopy"), and transitions with a fringe of shrubs between the páramo and the forest ("fringed"). The transitions in the classes "medium abrupt" and "gradual" were always fringed. If many small patches of forest occurred above the continuous treeline, the treeline was considered to be "patchy."
However, large single forest patches above an abrupt treeline were not considered part of the treeline structure. These patches may be extra-zonal islands in favorable microsites or may be remnants of a previously more extensive forest (Miehe and Miehe, 1994; Kessler, 2002); this issue is unresolved for most areas and is not part of this research.

\section{TEMPERATURES}

Air and topsoil temperatures were measured using $\mathrm{HOBO} \mathrm{H} 8$ Outdoor 4-Channel External Data Loggers (Onset Corporation) with external temperature probes. Temperature probes were installed in sets of four, placed together at 15,35 , and $150 \mathrm{~cm}$ above the ground and at $3 \mathrm{~cm}$ below the ground. Those above the ground were protected from direct sunlight by small roofs made from disposable aluminum muffin tins lined with Styrofoam. Temperature was always measured inside and outside the forest simultaneously at three locations both inside and outside, but due to equipment failure the number of repetitions was sometimes smaller. The temperature probes were placed so that they had no direct influence from nearby branches or leaves, but reflected the general microclimate. Temperatures were measured during three to eight days in six of the study areas where vegetation transects were made, and during one or two days in two additional study areas, where no transects were made (Table 3). Temperature was logged every two minutes.

Soil temperatures were measured once at each sample point along each transect, at $-12 \mathrm{~cm}$ and at $-28 \mathrm{~cm}$, provided that the soil layer was deep enough. A bi-metal steel soil thermometer (Reotemp, $1^{\circ} \mathrm{C}$ accuracy) was used for the measurements at $-28 \mathrm{~cm}$, and a digital steel thermometer $\left(1^{\circ} \mathrm{C}\right.$ accuracy, $0.1^{\circ} \mathrm{C}$ resolution) was used for the measurements at $-12 \mathrm{~cm}$. Average soil temperatures of sample points with high $(\geq 2 \mathrm{~m})$ and low $(<2 \mathrm{~m})$ vegetation, to distinguish between forest and páramo, were compared using Student's $t$-test. The difference between 'high' and low' vegetation is set at $2 \mathrm{~m}$, because this is half the minimum height of forest as used in the classification of boundaries.

\section{Results}

\section{TREELINE STRUCTURE}

In most areas treelines were abrupt in most transects (Table 2). Of these abrupt treelines most were 'fringed' (Figs. 2a and 3a). The fringe usually consisted of tall shrubs, Blechnum ferns, tall Neurolepis grass (Northern Andes), or trees with canopies down to ground level (Tafi del Valle). Treelines with 
TABLE 3

Summary of temperature data from a representative selection of sensors at $-3 \mathrm{~cm}$ (in topsoil), $15 \mathrm{~cm}$, and $150 \mathrm{~cm}$ above the soil surface, in forest (shaded) and in alpine vegetation in different study areas. Temperature was registered by shaded sensors and stored in dataloggers every 2 minutes for several days.

\begin{tabular}{|c|c|c|c|c|c|c|c|c|c|c|}
\hline \multirow[b]{2}{*}{ Area Start date } & \multirow[b]{2}{*}{ Weather } & \multirow{2}{*}{$\begin{array}{l}\text { Start } \\
\text { time }\end{array}$} & \multirow{2}{*}{$\begin{array}{l}\text { Duration } \\
\text { d:h:m }\end{array}$} & \multirow[b]{2}{*}{ Vegetation } & \multicolumn{2}{|c|}{$\mathrm{T}$ at $-3 \mathrm{~cm}\left({ }^{\circ} \mathrm{C}\right)$} & \multicolumn{2}{|c|}{$\mathrm{T}$ at $15 \mathrm{~cm}\left({ }^{\circ} \mathrm{C}\right)$} & \multicolumn{2}{|c|}{$\mathrm{T}$ at $150 \mathrm{~cm}\left({ }^{\circ} \mathrm{C}\right)$} \\
\hline & & & & & mean (sd) & $\min -\max$ & mean (sd) & $\min -\max$ & mean (sd) & $\min -\max$ \\
\hline \multirow{3}{*}{$\begin{array}{l}\text { Boca del Monte } \\
\text { (23 Jan 04) }\end{array}$} & Clear nights, $2.5 \mathrm{~d}$ & $12: 30$ & $4: 03: 05$ & Moist mossy cloud forest & $8.4(0.9)$ & $7.0-9.8$ & $8.1(3.8)$ & $2.0-20.2$ & $8.3(3.1)$ & $2.9-19.0$ \\
\hline & cloudy, $2.5 \mathrm{~d}$ sunny & $12: 15$ & $4: 03: 15$ & $\begin{array}{l}\text { Dense shrub-tussock grass } \\
\text { páramo }\end{array}$ & $8.0(2.3)$ & $5.0-13.3$ & $8.9(7.7)$ & $-4.3-29.9$ & $9.0(3.2)$ & $2.5-19.0$ \\
\hline & & $11: 10$ & 4:05:10 & $\begin{array}{l}\text { Burned open tussock grass } \\
\text { páramo }\end{array}$ & $13.0(7.5)$ & $2.9-34.9$ & $9.2(6.9)$ & $-1.5-27.5$ & \multicolumn{2}{|c|}{ no data } \\
\hline \multirow{2}{*}{$\begin{array}{l}\text { La Aguada } \\
\qquad(5 \text { Feb 04) }\end{array}$} & Clear nights and & 19:00 & $1: 12: 45$ & Relatively dry páramo forest & $6.3(1.7)$ & $3.7-9.0$ & $6.0(4.3)$ & $0.7-16.4$ & $6.6(4.1)$ & $1.2-16.4$ \\
\hline & $\begin{array}{l}\text { mornings, clouds } \\
\text { from ca. } 15 \text { to } 20 \mathrm{~h}\end{array}$ & $18: 05$ & $1: 13: 50$ & $\begin{array}{l}\text { Medium open shrub-tussock } \\
\text { páramo }\end{array}$ & $7.3(5.7)$ & $0.7-21.7$ & $2.2(11.7)$ & $-10.6-28.3$ & $5.5(4.2)$ & $-1.5-14.1$ \\
\hline \multirow{2}{*}{$\begin{array}{l}\text { Guandera } \\
\qquad(13 \text { Nov 03) }\end{array}$} & Alternately clear / & $11: 30$ & $7: 04: 30$ & Moist mossy cloud forest & $7.1(1.5)$ & $3.7-12.6$ & $7.0(2.3)$ & $2.5-15.2$ & $7.0(2.3)$ & $2.0-13.7$ \\
\hline & cloudy / rainy & $12: 00$ & 7:03:00 & Dense tussock grass páramo & $9.7(1.4)$ & $6.6-14.1$ & $8.5(6.4)$ & $-2.4-31.9$ & $7.7(2.9)$ & $2.0-19.0$ \\
\hline \multirow{2}{*}{$\begin{array}{l}\text { Atillo } \\
\qquad(18 \text { Dec } 03)\end{array}$} & Continuous clouds / & $13: 30$ & $1: 21: 30$ & Moist Escallonia forest & $6.3(0.2)$ & $5.8-6.6$ & $6.1(0.5)$ & $5.0-7.8$ & $5.9(0.4)$ & $5.0-7.4$ \\
\hline & fog, rain and wind & $12: 30$ & $1: 22: 30$ & Dense tussock grass páramo & $7.0(0.4)$ & $6.6-7.8$ & $6.0(0.8)$ & $5.0-8.6$ & $5.9(0.4)$ & $5.0-7.4$ \\
\hline \multirow{3}{*}{$\begin{array}{l}\text { La Libertad } \\
\qquad(6 \text { Dec } 03)\end{array}$} & Alternately clear / & $14: 15$ & $5: 23: 45$ & Dry mossy forest & $8.8(1.0)$ & $6.6-11.4$ & $8.5(2.3)$ & $3.7-16.0$ & $8.7(2.2)$ & $4.6-17.1$ \\
\hline & cloudy, some rain & $13: 45$ & $6: 00: 45$ & Transition: young trees, $3-4 \mathrm{~m}$ & $9.4(1.4)$ & $7.0-15.2$ & $9.4(3.3)$ & $3.3-21.7$ & $9.6(3.4)$ & $5.0-22.1$ \\
\hline & & 13:05 & $6: 01: 25$ & Dense tussock grass páramo & $12.1(2.3)$ & $8.6-21.0$ & $11.2(6.6)$ & $1.2-36.1$ & $9.0(3.0)$ & $4.2-19.8$ \\
\hline \multirow{2}{*}{$\begin{array}{l}\text { El Tiro } \\
\qquad(30 \text { Nov 03) }\end{array}$} & Alternately clear / & $15: 30$ & $3: 00: 30$ & Moist mossy cloud forest & $11.2(0.8)$ & $10.2-13.3$ & $10.9(1.6)$ & $8.6-16.0$ & $11.0(2.1)$ & $8.2-17.9$ \\
\hline & $\begin{array}{l}\text { cloudy / misty, no } \\
\text { rain }\end{array}$ & $13: 35$ & $3: 02: 25$ & Low $(<30 \mathrm{~cm})$ shrub páramo & $13.2(1.9)$ & $11.4-18.7$ & $13.1(5.1)$ & $8.6-31.5$ & $11.5(2.9)$ & $7.8-21.3$ \\
\hline \multirow{2}{*}{$\begin{array}{l}\text { Keara } \\
\qquad(7 \text { Sep 03) }\end{array}$} & $1.5 \mathrm{~d}$ clear, $1.5 \mathrm{~d}$ & $17: 00$ & $2: 16: 45$ & Moist mossy cloud forest & $6.8(1.2)$ & $4.6-10.2$ & $6.8(2.1)$ & $3.3-12.6$ & $7.0(2.1)$ & $3.3-12.9$ \\
\hline & cloudy and rainy & $17: 00$ & $2: 16: 45$ & $\begin{array}{l}\text { Medium open tussock grass } \\
\text { páramo }\end{array}$ & $10.5(3.2)$ & $5.8-18.7$ & $8.3(5.2)$ & $2.0-24.4$ & $7.8(3.0)$ & $3.7-16.4$ \\
\hline $\begin{array}{l}\text { Tafi del Valle } \\
\qquad(28 \text { Sep 03) }\end{array}$ & $\begin{array}{l}\text { Alternately clear / light } \\
\text { cloud cover }\end{array}$ & $15: 00$ & 3:01:30 & Dense tussock grass & $17.0(8.0)$ & $5.8-35.3$ & $17.3(9.4)$ & $0.7-38.3$ & $15.2(6.6)$ & $0.7-27.9$ \\
\hline
\end{tabular}

overhanging canopies (Fig. 2b) were found mostly in Guandera and Tafi del Valle. Medium and gradual treelines (Figs. 2c, 2d, $3 \mathrm{~b}, 3 \mathrm{c})$ were principally found in La Libertad and in El Tiro, and some in Boca del Monte. Patchy treelines (Fig. 2e) were found in Keara on the north-facing, sunny slope, and on Haleakala. In both cases the forest patches themselves had abrupt to medium abrupt boundaries, with either overhanging canopies or fringes, and occupied areas of about 4 to $25 \mathrm{~m}^{2}$.

Structure classes were based on vegetation height from the ground, and they were largely confirmed when looking at the absolute vegetation altitude (relative to a horizontal plane). The more gradual transects sometimes hardly showed any rise in absolute canopy altitude in spite of the increased vegetation height (Figs. 2c and 2d).

\section{TEMPERATURES}

Average air and topsoil temperatures and temperature variation in time (expressed in the standard deviation) were generally higher in the páramo than in the forest (Table 3). Exceptions were temperatures in the topsoil at Boca del Monte, which was heavily shaded by the páramo vegetation; air temperatures at La Aguada, where very low nighttime temperatures caused the average to be lower outside the forest; and air temperatures at Atillo, which were measured during a very cloudy and rainy period, resulting in homogeneous temperatures in both space and time. Differences between páramo and forest were generally largest in the topsoil and close to the ground (Table 3).

Temperature differences between night and day were most pronounced close to the ground (at $15 \mathrm{~cm}$ ), especially in the páramo (Fig. 4a). Temperatures in the upper soil layer were usually dampened compared to air temperature (Fig. 4). However, these temperatures could become much more extreme in dry and exposed soil, like the dry granitic sand soils in Tafi del Valle, and the soil under the open burnt páramo on the dry, west-facing slope at Boca del Monte (Table 3). In all cases the topsoil temperature had a smoother course through the day, and was delayed by a couple of hours compared to the air temperature (Fig. 4).

Soil temperatures at both -12 and $-28 \mathrm{~cm}$ were significantly higher under páramo than under forest in all areas, except in Tafi del Valle at both depths and in Haleakala at $-28 \mathrm{~cm}$ (Table 4). The standard deviation (here a measure for variation in space) was either the same in forest and páramo (equal variance according to Levene's test), or higher in páramo, reflecting a more heterogeneous shading of the soil in the páramo than in the forest.

Average soil temperatures at $-28 \mathrm{~cm}$ under forest, which should best reflect the average seasonal temperature, were highest in Haleakala and lowest in Keara and Guandera (Table 4). Coincidentally, Haleakala also has the treeline at the lowest altitude, followed by El Tiro and Tafi del Valle, while Guandera has the highest treeline (Table 1).

\section{Discussion}

Most areas had abrupt treelines, and the vertical structures of forest and páramo were surprisingly similar across a wide geographical range. The tropical Andes treelines, from Bolivia to Venezuela, coincided not only in structure, but also to a surprising extent in floristic composition (often to genus level, data not shown). Vertical structures of forest and páramo in Hawaii were again quite similar to those in most Andes sites, despite the different species composition. Only the mono-specific and simply structured Alnus forest in Tafi del Valle differed markedly from the diverse and complex cloud forests at the other sites, yet the alpine vegetation, though drier than the tropical páramos, consisted of high tussock grasses and the treeline was abrupt, like at most of the tropical sites. 


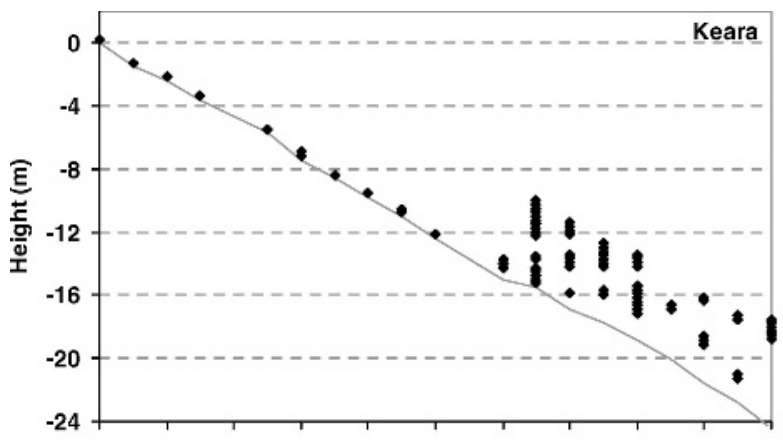

a.

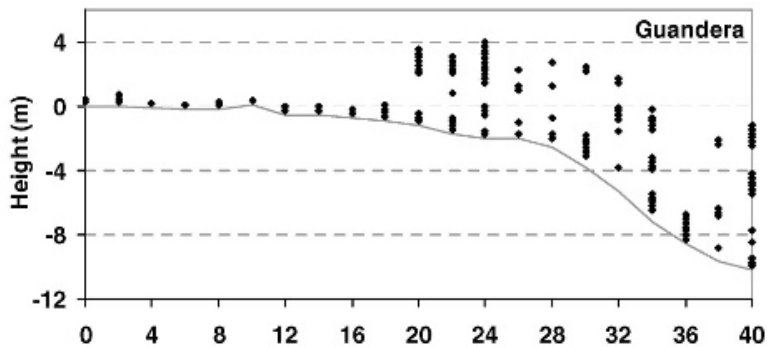

b.

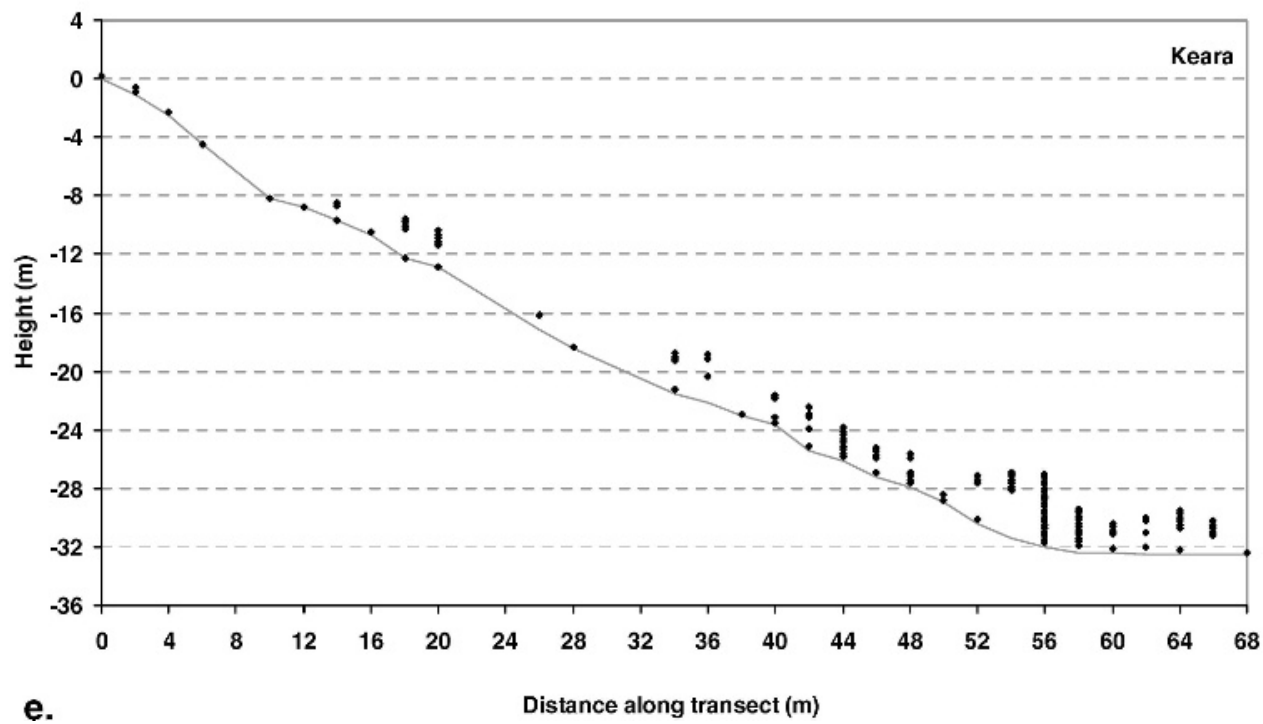

FIGURE 2. Examples of transect where the treeline is (a) abrupt and fringed, (b) abrupt with overhanging canopy, (c) medium abrupt, (d) gradual, and (e) patchy. The height of the underlying surface (gray line) and that of the vegetation (black diamonds) is plotted relative to the first plotted ground surface (set at distance 0). The $x$-axis is identical for the first four graphs.

Air and soil temperatures were generally lower under forest than under páramo. Temperature differences between day and night were much more pronounced in the páramo than in the forest, as were differences between clear and cloudy days, and between air close to the ground and air higher up. These differences are all related to the radiation regime. Irradiance can be strong year-round at tropical treelines, due to the high altitude combined with the low latitude. On clear days, the páramo surface and the air just above it warm up strongly during the day and cool down strongly during the night due to radiation. In contrast, the forest interior is protected by the canopy and therefore maintains a relatively constant and low temperature. The similarity in soil

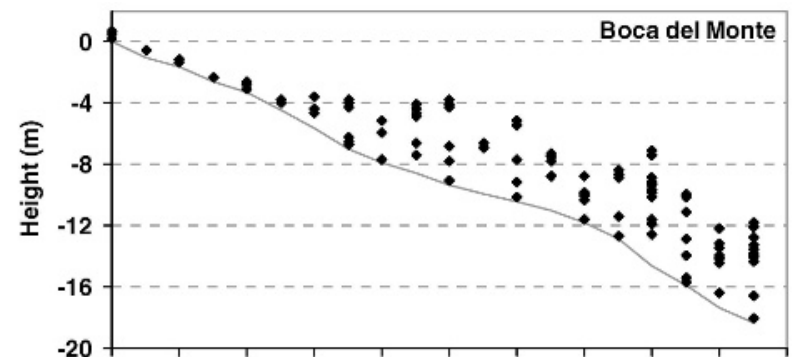

c.

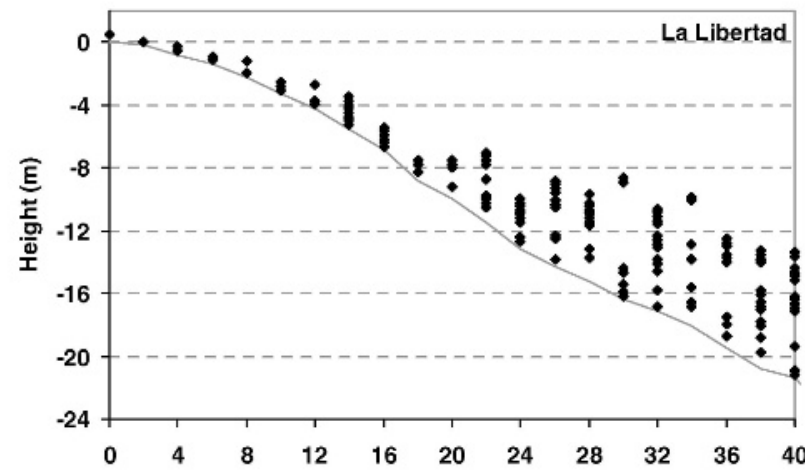

d.

temperatures in and outside the forest in Tafi del Valle, in contrast to the differences found in other areas, is almost certainly due to lack of shade under this forest, which is composed of deciduous Alnus trees that were without leaves during the measurements.

Soil temperatures were measured only once at each point along the transects, and the different points in a study area were measured within a few days. The measured soil temperatures may therefore not accurately represent the average yearly temperature. However, thermal seasonality is low in most of our study areas, and there is no seasonal bias in the timing of our measurements. It is therefore remarkable that the soil temperatures in all study areas were higher than the average growing season temperatures 


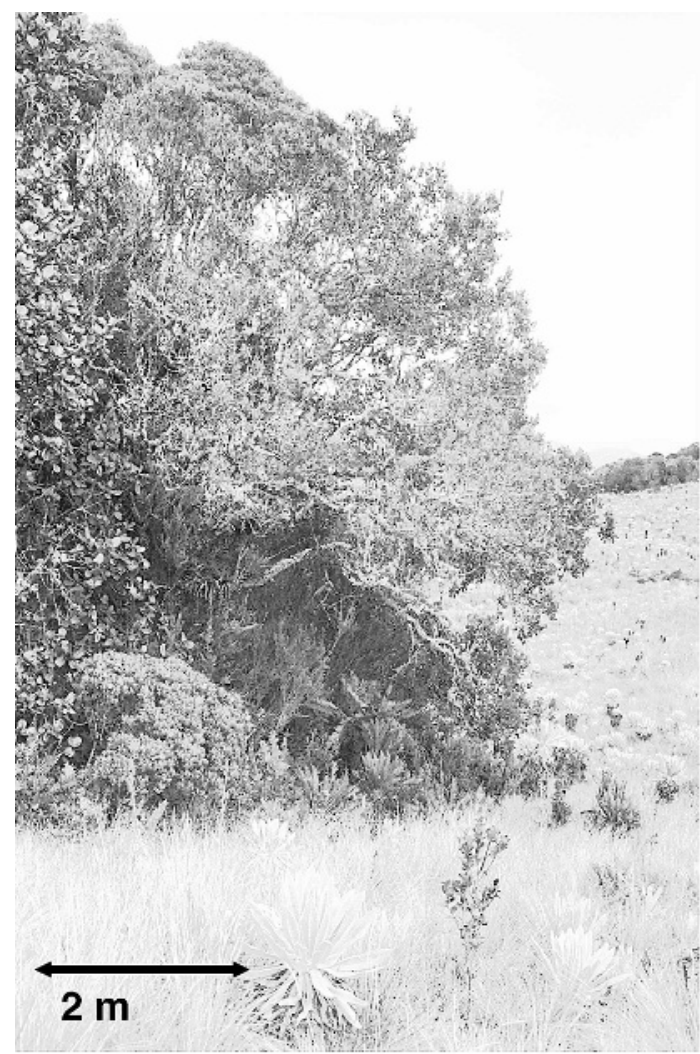

a.

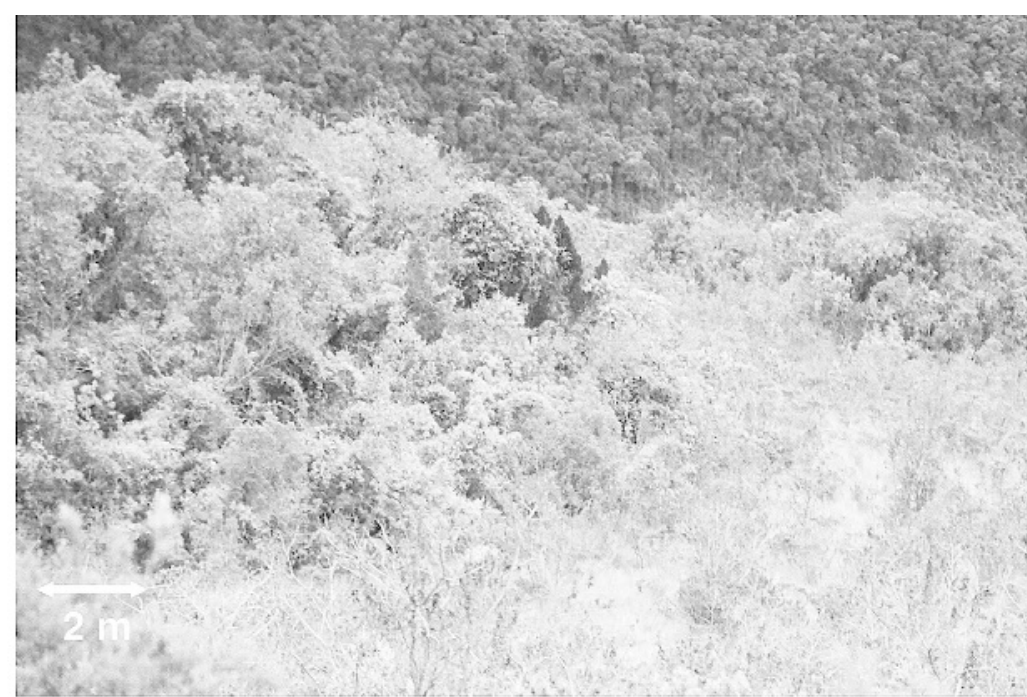

b.

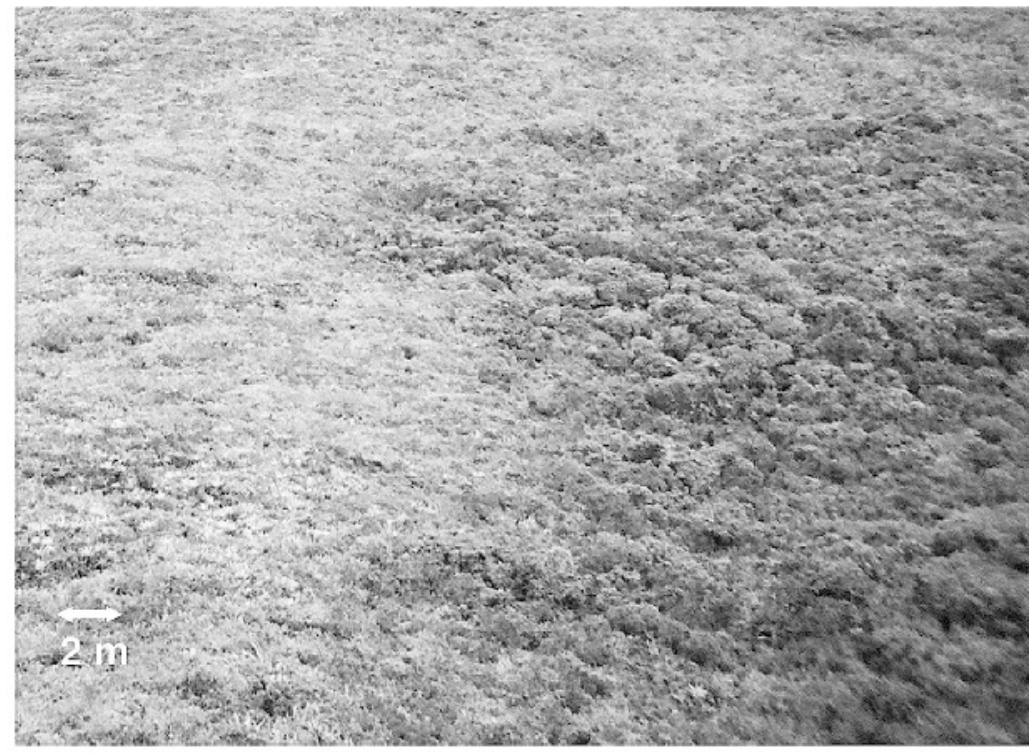

c.

FIGURE 3. Photos show (a) an abrupt treeline in Guandera, (b) a medium abrupt treeline on Pasochoa (Ecuador; not a study site), and (c) a gradual treeline at El Tiro. Arrows show approximate scale.

measured recently at 30 treelines worldwide (at $-10 \mathrm{~cm}$ and in the shade of trees) (Körner and Paulsen, 2004), which were mostly between 6 and $8^{\circ} \mathrm{C}$. In contrast to our data, the three tropical sites included in the global comparison (Körner and Paulsen, 2004) had relatively low growing season means $\left(4.5-6.7^{\circ} \mathrm{C}\right)$, the growing season being year-round or nearly so. This is in accordance with other studies at tropical treelines (Winiger, 1979; Ohsawa, 1990; Miehe and Miehe, 1994; Bendix and Rafiqpoor, 2001).

The fact that we measured higher soil temperatures could indicate that the treelines in our study areas are situated below their potential climatic altitude, which would be in accordance with the dominant view that actual tropical treelines are to a great extent anthropogenic features (Ellenberg, 1966; Laegaard, 1992; Miehe and Miehe, 1994; Ellenberg, 1996; Young and Keating, 2001; Kessler, 2002). However, the fact that other studies found lower soil temperatures could also indicate a bias of these studies toward the uppermost forest patches above treeline, which some consider representatives of the natural treeline (Laegaard, 1992; Sarmiento and Frolich, 2002), but which others consider extra- zonal islands in locally favorable sites (Troll, 1959; Walter and Medina, 1969; Lauer, 1988). In many cases the climatic treeline is probably situated somewhere in between the present treeline and the uppermost forest patches (Miehe and Miehe, 1994; Kessler, 2002; Wille et al., 2002), and the mean annual temperature at this climatic treeline would be somewhere between 5 and $9^{\circ} \mathrm{C}$, which is in accordance with the global pattern (Körner and Paulsen, 2004). However, too few temperature data from 'natural' tropical treelines are available as a reference to be conclusive about this issue. The treeline on Haleakala (Hawaii) is a special case. This treeline is relatively low, and soil temperatures were higher than those at the Andean treelines, because the native tree species are less adapted to the high altitude environment than species on the continents. This is clear from the fact that a full grown exotic pine plantation grows above the native treeline.

In spite of the global coincidence of treelines at similar average growing season temperatures (Körner and Paulsen, 2004), these average temperatures can hardly be expected to directly control treeline position. In fact, we found that average 


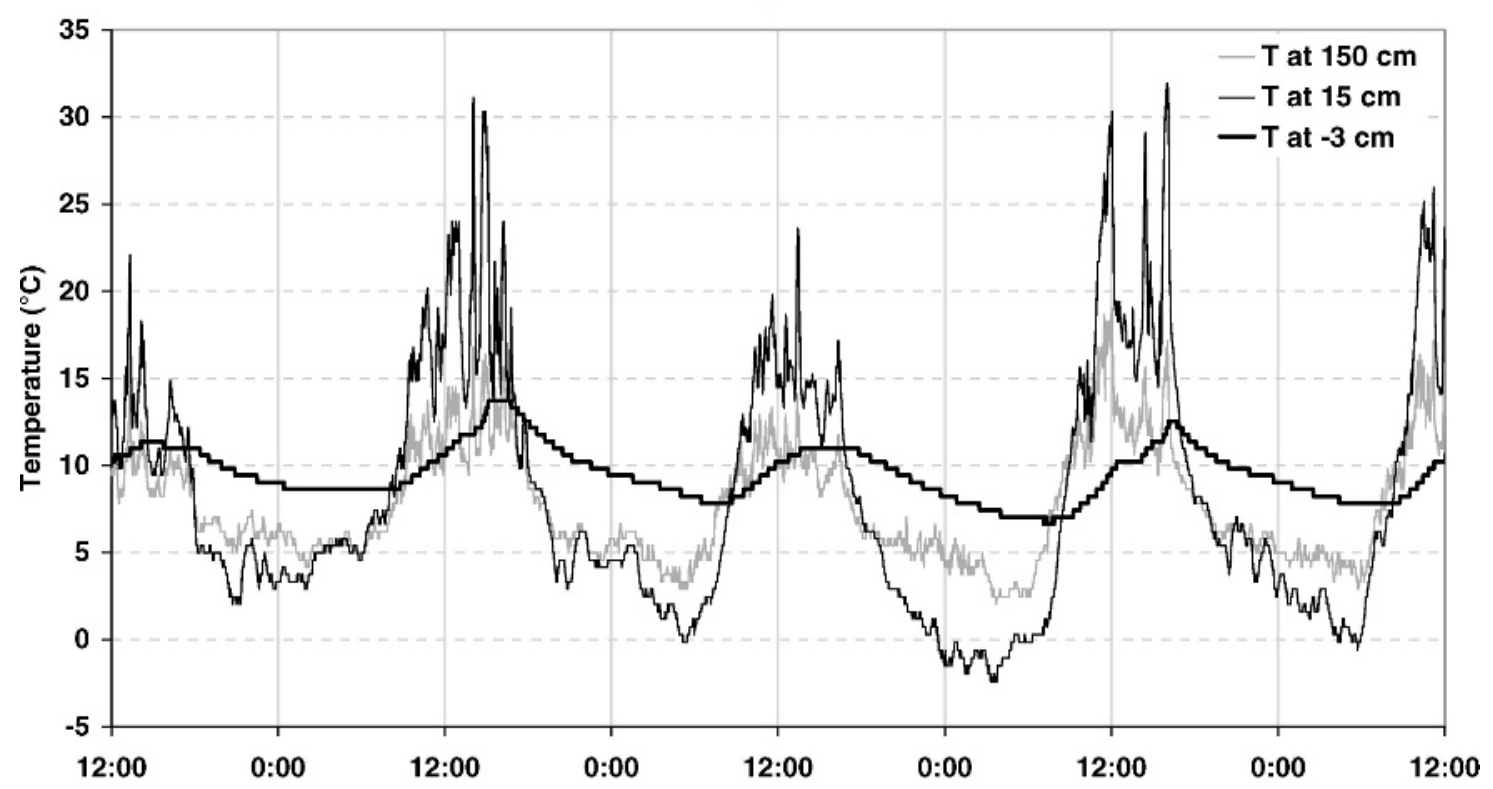

a.

Time (November 15-19 2003)

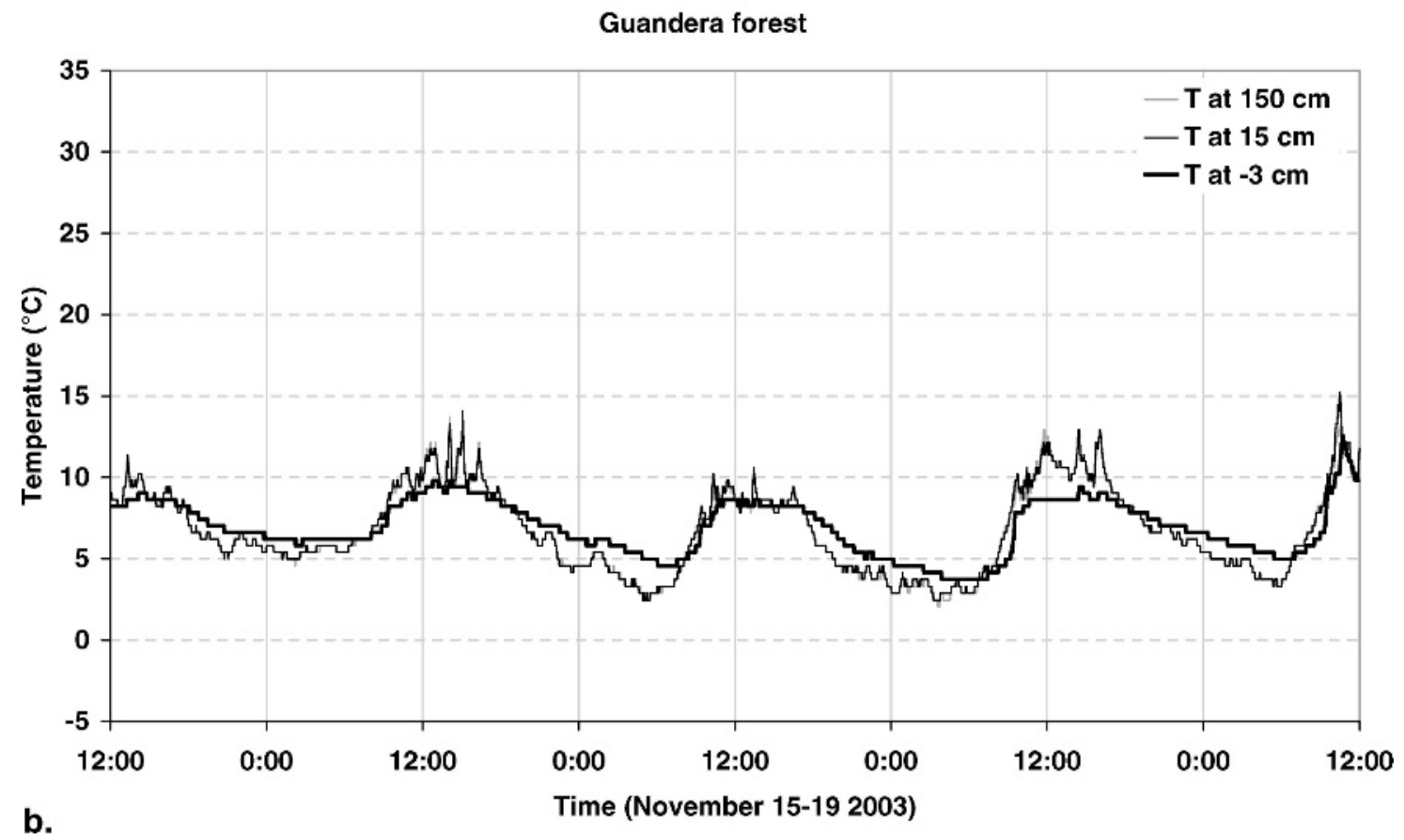

FIGURE 4. Temperatures in Guandera during 4 days. (a) In the páramo, and (b) in the forest (the temperature at $15 \mathrm{~cm}$ and at $150 \mathrm{~cm}$ coincide strongly, which is the reason why only two lines can be seen in most of the graph). The weather during these days: 15 November, sunny in the early morning (not shown), then cloudy with drizzly rain; 16 November, cloudy morning, sunny afternoon, rain at night; 17 November, cloudy all day; 18 November, sunny morning, thick clouds from just before midday, some light rain in the afternoon; 19 November, sunny morning with some clouds.

temperatures were higher above the treeline than in the forest, a finding that is confirmed in several other tropical (Azócar and Monasterio, 1980; Miehe and Miehe, 1994; Kessler and Hohnwald, 1998; Bendix and Rafiqpoor, 2001) and worldwide (Körner and Paulsen, 2004) treeline temperature studies. Low soil temperatures probably also do not limit tree regeneration, because these were also higher in the páramo and higher than the lower threshold of $5-7^{\circ} \mathrm{C}$ for the growth of most tree species (Körner and Hoch, 2006). More likely, the mechanisms restricting tree growth above the treeline are related to the extreme temperatures that occur here, especially the low night temperatures followed by strong solar radiation during the day, causing photoinhibition or more serious damage to unprotected plants (Wardle, 1965; Ball et al., 1991; Germino and Smith, 1999; Bader et al., 2007). The highest standard deviation and most extreme minimum and maximum air temperatures are almost always found in the páramo at $15 \mathrm{~cm}$ above the ground. This implies that this air layer close to the ground has the most stressful temperature conditions for plants, including sub-freezing temperatures at night. Páramo plants are well adapted to these conditions (Rundel 
TABLE 4

Mean soil temperatures in forest (vegetation height $\geq 2 \mathrm{~m}$ ) and in páramo (vegetation height $<2 \mathrm{~m}$ ) at $-12 \mathrm{~cm}$ and at $-28 \mathrm{~cm}$, per study area; mean (bold), standard deviation and number of sample points $(n)$. Also shown are the differences between mean temperatures in páramo and forest $\left(T_{\text {páramo }}-T_{\text {forest }}\right)$ and their significance according to Student's $t$-tests.

\begin{tabular}{|c|c|c|c|c|c|}
\hline & & \multicolumn{2}{|c|}{$-12 \mathrm{~cm}$} & \multicolumn{2}{|c|}{$-28 \mathrm{~cm}^{\mathrm{a}}$} \\
\hline & & mean $\mathrm{T}\left({ }^{\circ} \mathrm{C}\right)$ & $\mathrm{T}_{\text {páramo }}-\mathrm{T}_{\text {forest }} t$-statistic ${ }^{\mathrm{b}}$ & mean $\mathrm{T}\left({ }^{\circ} \mathrm{C}\right)$ & $\mathrm{T}_{\text {páramo }}-\mathrm{T}_{\text {forest }} t$-statistic ${ }^{\mathrm{b}}$ \\
\hline \multirow[t]{4}{*}{ Boca del Monte } & forest & 9.4 & & 9.5 & \\
\hline & & $\mathrm{sd}=1.3 n=98$ & & $\mathrm{sd}=1.1 n=75$ & \\
\hline & páramo & 10.9 & 1.5 & 9.7 & 0.2 \\
\hline & & $\mathrm{sd}=2.7 n=78$ & $4.48 * * \mathrm{NE}$ & $\mathrm{sd}=1.3 n=33$ & $1.02 \mathrm{E}$ \\
\hline \multirow[t]{4}{*}{ Guandera } & forest & 8.7 & & 9.0 & \\
\hline & & $\mathrm{sd}=0.8 n=108$ & & $\mathrm{sd}=0.7 n=108$ & \\
\hline & páramo & 10.0 & 1.3 & 10.1 & 1.1 \\
\hline & & $\mathrm{sd}=1.1 n=134$ & $10.13^{* *} \mathrm{NE}$ & $\mathrm{sd}=0.9 n=134$ & $11.44^{* *} \mathrm{NE}$ \\
\hline \multirow[t]{4}{*}{ La Libertad } & forest & 10.3 & & 9.9 & \\
\hline & & $\mathrm{sd}=1.0 n=64$ & & $\mathrm{sd}=0.6 n=60$ & \\
\hline & páramo & 11.3 & 1.0 & 11.0 & 1.1 \\
\hline & & $\mathrm{sd}=0.8 n=63$ & $5.69 * * \mathrm{E}$ & $\mathrm{sd}=0.6 n=39$ & $8.70^{* *} \mathrm{E}$ \\
\hline \multirow[t]{4}{*}{ El Tiro } & forest & 11.9 & & 11.3 & \\
\hline & & $\mathrm{sd}=0.7 n=22$ & & $\mathrm{sd}=0.5 n=22$ & \\
\hline & páramo & 13.0 & 1.1 & 11.8 & 0.5 \\
\hline & & $\mathrm{sd}=1.1 n=31$ & $4.11 * * \mathrm{E}$ & $\mathrm{sd}=0.7 n=32$ & $3.22 * \mathrm{E}$ \\
\hline \multirow[t]{4}{*}{ Keara } & forest & 9.1 & & 8.9 & \\
\hline & & $\mathrm{sd}=1.4 n=76$ & & $\mathrm{sd}=0.8 n=63$ & \\
\hline & páramo & 10.9 & 1.8 & 9.7 & 0.8 \\
\hline & & $\mathrm{sd}=2.1 n=127$ & $7.24 * * \mathrm{NE}$ & $\mathrm{sd}=0.7 n=73$ & $6.56^{* *} \mathrm{E}$ \\
\hline \multirow[t]{4}{*}{ Tafi del Valle } & forest & 11.5 & & 9.9 & \\
\hline & & $\mathrm{sd}=2.5 n=104$ & & $\mathrm{sd}=1.4 n=77$ & \\
\hline & páramo & 12.1 & 0.6 & 10.3 & 0.4 \\
\hline & & $\mathrm{sd}=3.2 n=96$ & $1.59 \mathrm{NE}$ & $\mathrm{sd}=1.5 n=65$ & $1.55 \mathrm{E}$ \\
\hline \multirow[t]{4}{*}{ Haleakala } & forest & 14.8 & & 14.5 & \\
\hline & & $\mathrm{sd}=1.9 n=69$ & & $\mathrm{sd}=0.5 n=18$ & \\
\hline & páramo & 15.7 & 0.9 & 14.8 & 0.3 \\
\hline & & $\mathrm{sd}=0.8 n=113$ & $4.30^{* *} \mathrm{E}$ & $\mathrm{sd}=0.4 n=36$ & $1.88 \mathrm{NE}$ \\
\hline
\end{tabular}

\footnotetext{
${ }^{a}$ Excluded are points where the thermometer probe could not enter the soil more than $24 \mathrm{~cm}$.

${ }^{\mathrm{b}}$ Difference between mean temperature in forest and in páramo per area and $t$-statistic (independent sample student's $t$-test). NE and E refer to the equality of the variances according to a Levene's test. If variances are not equal (NE), the reported $t$ values are those of an adjusted $t$-test. This adjusted test gave the same conclusion of significance as an unadjusted test in all cases. Significance of $t$-statistic: ${ }^{*} p<0.05,{ }^{*} p<0.001$.
}

et al., 1994), but this may not be true for young trees, which consequently cannot establish outside the forest (Bader et al., 2007). The different temperature regimes in forest and páramo may therefore be an important factor in the stabilization and shaping of treelines, especially where fire is not an overriding factor.

If the climate above the treeline is too harsh for tree establishment, while the climate inside the forest allows tree establishment and growth, a positive feedback is operating. Positive feedback occurs when plant communities modify their environment in such a way that they favor themselves relative to other communities. This causes a sharpening of boundaries (Wilson and Agnew, 1992). Additionally, positive feedback can cause non-linear reactions to changes in climate (Kupfer and Cairns, 1996; Malanson, 2001; Smith et al., 2003). Knowing the origin of the abruptness of treelines is therefore also relevant for predictions of the vegetation response to climatic changes.

Of the studied tropical treelines, even the relatively gradual ones were more abrupt than the 'sharp' Russian treelines described by Armand (1992), where the transition from forest to alpine vegetation was about $20 \mathrm{~m}$ long. It is assumed by many authors that the abruptness of treelines in the tropics indicates an anthropogenic origin (Miehe and Miehe, 1994). Unfortunately, in the Andes, and maybe everywhere in the tropics, it is almost if not totally impossible to find a treeline that with certainty has not suffered human influence in the past (Miehe and Miehe, 2000). Therefore, no good reference sites are available that would help us to separate the influence of anthropogenic and natural processes on treeline structure. To study these processes in detail, experimental research would be necessary, for instance the exclusion of each of the processes that are expected to be important (Bader et al., 2007).

The La Libertad area has consciously not been burnt for over a decade, providing us with a natural fire-exclusion experiment. The treeline here is more gradual because of regenerating trees in the páramo close to the former treeline, indicating the strong control that fire had previously on the position and probably the structure of this treeline. Fire can cause abrupt treelines due to a positive feedback between fuel (páramo, relatively flammable due to dry dead biomass) and fire (preventing forest growth and thus maintaining the páramo) (Vilà et al., 2001; van Langevelde et al., 2003). This control may be important in many of the study areas, as fire is a common phenomenon in all areas except El Tiro and Haleakala. In El Tiro fire does not occur or rarely occurs because of the very wet circumstances, and the most gradual treelines were found here. However, it cannot be concluded from this that treelines without fire should always be gradual, because the circumstances at El Tiro are quite exceptional, with strong winds shearing the vegetation. In the Haleakala site, where fire is also uncommon, there were more forest patches above treeline 
than at most other study sites, but these had abrupt boundaries. So although fires occur in many areas, we have no information about the actual effect of fires on treelines. Therefore, the possibility that other mechanisms such as alterations of the temperature regime can also produce abrupt treelines should not be excluded.

We found patchy treelines in two sites where the reason for the observed patchiness is probably very different. In Keara the patchy treeline was located on a steep north-facing slope. This relatively dry and warm slope was favored for agriculture, and old fields were located close to the transects. In the forest, cattle paths were evident. It seems likely that this part of the forest has been opened up by cattle and farmers, and it may even be secondary forest. Grazing might thus break up a treeline (Tranquillini, 1979), which is in contrast to the dominant view that grazing makes treelines more abrupt (Cairns and Moen, 2004), like fire does. Cattle were observed to enter the forest also in Boca del Monte, but here the effect was restricted to the undergrowth, while trees remained intact and the treeline remained closed. In contrast, the patchy treeline on Haleakala was little disturbed, except by some feral pigs and deer, and here the patchiness may well be the natural treeline pattern. In the Andes natural treelines may also have a patchy character, as seen in the sub-páramo zone recognized in Colombia (Cuatrecasas, 1958; Van Der Hammen and Cleef, 1986), and recently at a unique pristine and very wet treeline in Ecuador (Robert Hofstede, personal communication, 2006). However, this cannot be confirmed or refuted based on direct evidence, because natural treelines are so rare.

Although different positive feedback processes may result in similar spatial patterns, knowing which is dominant at a given treeline is essential for predicting its reaction to changes in climate or land use. To distinguish between the various anthropogenic and natural processes involved in shaping treelines, further field experiments are recommended. In these experiments each of the potentially important processes should be excluded in a factorial design, and vegetation development should be monitored. A first experiment, addressing solar radiation, neighbor interactions, and soil limitations, was conducted at a treeline in northern Ecuador recently and supports the hypothesis that the harsh microclimate outside the forest hinders tree regeneration (Bader et al., 2007). Additionally, spatially explicit simulation models can be used to study the potential effects of the relevant processes on spatial vegetation patterns and dynamics, including the reaction of treelines to environmental changes (e.g. Noble, 1993; Alftine and Malanson, 2004; Dullinger et al., 2004; Wiegand et al., 2006; Bader et al., in review).

\section{Acknowledgments}

We thank Germán Vargas Buitrago and Rolando Paredes for their assistance and company in the field, Ecopar (Quito, Ecuador), Guandera Estación Biológica (Mariscal Sucre, Ecuador), Herbario Loja (Loja, Ecuador), Fundación Cordillera Tropical (Cuenca, Ecuador), Parque Nacional Sangay (Riobamba, Ecuador), Herbario Nacional de Bolivia (La Paz), ICAE Universidad de los Andes (Mérida, Venezuela), Ricardo Grau (Tucumán, Argentina), Pat Bily (TNC, Maui, Hawaii), and many others for their logistic support, advice, help, and companionship. We thank Karsten Wesche and two anonymous reviewers for useful comments on the manuscript. Fieldwork was possible thanks to financial support from Stichting Prins Bernhard Cultuurfonds (The Netherlands) and a travel grant from the Netherlands Organization for Scientific Research (NWO). The research of Rietkerk is supported by a VIDI grant from the same organization, division Earth and Life Sciences (NWO-ALW).

\section{References Cited}

Alftine, K. J., and Malanson, G. P., 2004: Directional positive feedback and pattern at an alpine tree line. Journal of Vegetation Science, 15: 3-12.

Armand, A. D., 1985: The change of vegetation near the timberline. Inter-Nord, 17: 59-62.

Armand, A. D., 1992: Sharp and gradual mountain timberlines as a result of species interaction. In Hansen, A. J., and di Castri, F. (eds.), Landscape boundaries: consequences for biotic diversity and ecological flows. New York: Springer.

Azócar, A., and Monasterio, M., 1980: Estudios de la variabilidad meso y microclimática en el Páramo de Mucubají. In Monasterio, M. (ed.), Estudios ecológicos en los páramos andinos. Mérida: Ediciones de la Universidad de Los Andes, 225-262.

Bader, M. Y., Rietkerk, M., and Bregt, A. K., 2007: High solar radiation hinders tree regeneration above the alpine treeline in northern Ecuador. Plant Ecology, 191: 33-45.

Ball, M. C., Hodges, V. S., and Laughlin, G. P., 1991: Coldinduced photoinhibition limits regeneration of snow gum at tree-line. Functional Ecology, 5: 663-668.

Bekker, M. F., 2005: Positive feedback between tree establishment and patterns of subalpine forest advancement, Glacier National Park, Montana, U.S.A. Arctic, Antarctic, and Alpine Research, 37: 97-107.

Bendix, J., and Rafiqpoor, M. D., 2001: Studies on the thermal conditions of soils at the upper tree line in the páramo of Papallacta (Eastern Cordillera of Ecuador). Erdkunde, 55: 257-276.

Bühler, 1897/1898: Studien über die Baumgrenze im Hochgebirge. Berichten der Schweizerischen Botanischer Gesellschaft.

Cairns, D. M., and Moen, J., 2004: Herbivory influences tree lines. Journal of Ecology, 92: 1019-1024.

Cairns, D. M., and Waldron, J. D., 2003: Sigmoid wave transitions at alpine treeline. Geografiska Annaler Series APhysical Geography, 85A: 115-126.

Camarero, J. J., Gutiérrez, E., and Fortin, M.-J., 2000: Boundary detection in altitudinal treeline ecotones in the Spanish Central Pyrenees. Arctic, Antarctic, and Alpine Research, 32: 117-126.

Cavieres, L. A., Rada, F., Azócar, A., García-Núñez, C., and Cabrera, H. M., 2000: Gas exchange and low temperature resistance in two tropical high mountain tree species from the Venezuelan Andes. Acta Oecologica, 21: 203-211.

Cuatrecasas, J., 1958: Aspectos de la vegetación natural de Colombia. Revista de la Academia Colombiana de Ciencias Exactas, Físicas y Naturales, 10: 221-269.

Didier, L., and Brun, J.-J., 1998: Limite supraforestière et changements environnementaux: pour une approche pluriscalaire et spatialisée des ecosystèmes d'altitude. Géographie physique et Quarternaire, 52: 245-253.

Dullinger, S., Dirnbock, T., and Grabherr, G., 2004: Modelling climate change-driven treeline shifts: relative effects of temperature increase, dispersal and invasibility. Journal of Ecology, 92: 241-252.

Ellenberg, H., 1966: Leben und Kampf an den Baumgrenzen der Erde. Naturwissenschaftliche Rundschau, 4: 133-139.

Ellenberg, H., 1996: Paramos und Punas der Hochanden suedamerikas, heute grossenteils als potentielle Waelder anerkannt. Verhandlungen der Gesellschaft für Oekologie, 25: 17-24.

Fortin, M.-J., 1994: Edge-detection algorithms for 2-dimensional ecological data. Ecology, 75: 956-965.

Germino, M. J., and Smith, W. K., 1999: Sky exposure, crown architecture, and low-temperature photoinhibition in conifer seedlings at alpine treeline. Plant, Cell and Environment, 22: 407-415.

Grace, J., Berninger, F., and Nagy, L., 2002: Impacts of climate change on the tree line. Annals of Botany, 90: 537-544.

Graumlich, L. J., Waggoner, L. A., and Bunn, A. G., 2004: Detecting global change at alpine treeline: coupling paleoecol- 
ogy with contemporary studies. In Huber, U., Bugmann, H., and Reasoner, M. (eds.), Global change and mountain regions: a state of knowledge overview. Dordrecht: Springer, 405-412.

Hamilton, L. S., Juvik, J. O., and Scatena, F. N., 1995: Tropical montane cloud forests. New York: Springer Verlag, $407 \mathrm{pp}$.

Handa, I. T., Körner, C., and Hättenschwiler, S., 2005: A test of the treeline carbon limitation hypothesis by in situ $\mathrm{CO}_{2}$ enrichment and defoliation. Ecology, 86: 1288-1300.

Hoch, G., and Körner, C., 2003: The carbon charging of pines at the climatic treeline: a global comparison. Oecologia, 135: $10-21$.

Hofstede, R., Segarra, P., and Mena Vásconez, P., 2003: Los páramos del Mundo. Quito: Proyecto Atlas Mundial de los Páramos, Global Peatland Initiative/NC-IUCN/EcoCiencia.

Johnston, C. A., Pastor, J., and Pinay, G., 1992: Quantitative methods for studying landscape boundaries. In Hansen, A. J., and di Castri, F. (eds.), Landscape boundaries, consequences for biotic diversity and ecological flows. New York: Springer, 107-125.

Kessler, M., 2002: The "Polylepis problem": where do we stand? Ecotropica, 8: 97-110.

Kessler, M., and Hohnwald, S., 1998: Bodentemperaturen innerhalb und ausserhalb bewaldeter und unbewaldeter Blockhalden in den Bolivianischen Hochanden. Ein Test der Hypothese von Walter und Medina (1969). Erdkunde, 52: 54-62.

Kimball, K. D., and Weihrauch, D. M., 2000: Alpine vegetation communities and the alpine-treeline ecotone boundary in New England as biomonitors for climate change. Wilderness science in a time of change conference, No. RMRS-P-15 ( Vol. 3): 93-101.

Körner, C., 1998: A re-assessment of high elevation treeline positions and their explanation. Oecologia, 115: 445-459.

Körner, C., and Hoch, G., 2006: A test of treeline theory on a montane permafrost island. Arctic, Antarctic, and Alpine Research, 38: 113-119.

Körner, C., and Paulsen, J., 2004: A world-wide study of high altitude treeline temperatures. Journal of Biogeography, 31: 713-732.

Kullman, L., 1998: Tree-limits and montane forests in the Swedish Scandes: sensitive biomonitors of climate change and variability. Ambio, 27: 312-321.

Kupfer, J. A., and Cairns, D. M., 1996: The suitability of montane ecotones as indicators of global climatic change. Progress in Physical Geography, 20: 253-272.

Laegaard, S., 1992: Influence of fire in the grass páramo vegetation of Ecuador. In Balslev, H., and Luteyn, J. L. (eds.), Páramo. An Andean ecosystem under human influence. London: Academic Press, 151-170.

Lauer, W., 1978: Timberline studies in central Mexico. Arctic and Alpine Research, 10: 383-396.

Lauer, W., 1988: Zum Wandel der Vegetationszonierung in den Lateinamerikanischen Tropen seit dem Höhepunkt der letzten Eiszeit. In Buchholz, H. J., and Gerold, G. (eds.), Jahrbuch der Geographischen Gesellschaft zu Hanover, Lateinamerikaforschung, Hannover. Hannover: Selbstverlag der geographischen Gesellschaft, 1-45.

Leuschner, C., 1996: Timberline and alpine vegetation on the tropical and warm-temperate oceanic islands of the world: elevation, structure and floristics. Vegetatio, 123: 193-206.

Ludwig, J. A., and Cornelius, J. M., 1987: Locating discontinuities along ecological gradients. Ecology, 68: 448-450.

Malanson, G. P., 1997: Effects of feedbacks and seed rain on ecotone patterns. Landscape Ecology, 12: 27-38.

Malanson, G. P., 2001: Complex responses to global change at alpine treeline. Physical Geography, 22: 333-342.

Miehe, G., and Miehe, S., 1994: Zur oberen Waldgrenze in tropischen Gebirge. Phytocoenologia, 24: 53-110.

Miehe, G., and Miehe, S., 2000: Comparative high mountain research on the treeline ecotone under human impact. Carl
Troll's "Asymmetrical Zonation of the Humid Vegetation Types of the World" of 1948 reconsidered. Erdkunde, 54: 34-50.

Monasterio, M., 1980: Estudios ecológicos en los páramos andinos. Mérida: Ediciones de la Universidad de Los Andes, 310 pp.

Noble, I. R., 1993: A model of the responses of ecotones to climate change. Ecological Applications, 3: 396-403.

Norton, D. A., and Schönenberger, W., 1984: The growth forms and ecology of Nothofagus solandri at the alpine timberline, Craigieburn Range, New Zealand. Arctic and Alpine Research, 16: 361-370.

Ohsawa, M., 1990: An interpretation of latitudinal patterns of forest limits in south and east Asian mountains. Journal of Ecology, 78: 326-339.

Piper, F. I., Cavieres, L. A., Reyes-Díaz, M., and Corcuera, L. J., 2006: Carbon sink limitation and frost tolerance control performance of the tree Kageneckia aungustifolia D. Don (Rosaceae) at the treeline in central Chile. Plant Ecology, 185: 29-39.

Rundel, P. W., Smith, A. P., and Meinzer, F. C., 1994: Tropical alpine environments. Plant form and function. Cambridge: Cambridge University Press, 369 pp.

Sarmiento, F. O., and Frolich, L. M., 2002: Andean cloud forest tree lines: Naturalness, agriculture and the human dimension. Mountain Research and Development, 22: 278-287.

Smith, A. P., and Young, T. P., 1987: Tropical alpine plant ecology. Annual Review of Ecology and Systematics, 18: 137-158.

Smith, W. K., Germino, M. J., Hancock, T. E., and Johnson, D. M., 2003: Another perspective on altitudinal limits of alpine timberlines. Tree Physiology, 23: 1101-1112.

Stützer, A., 2000: Die Wald- und Baumgrenze der Saualpe: Ein Vergleich alter und neuer Bilder. Forstwissenschaftliches Centralblatt, 119: 20-31.

Timoney, K. P., Laroi, G. H., and Dale, M. R. T., 1993: Subarctic forest-tundra vegetation gradients-The sigmoid wave hypothesis. Journal of Vegetation Science, 4: 387-394.

Tranquillini, W., 1979: Physiological ecology of the Alpine timberline: tree existence at high altitudes with special reference to the European Alps. Berlin: Springer, $137 \mathrm{pp}$.

Troll, C., 1959: Die tropischen gebirge. Ihre dreidimensionale klimatische und pflanzengeographische Zonierung. Bonn: Ferd. Dümmlers.

Van Der Hammen, T., and Cleef, A. M., 1986: Development of the high Andean páramo flora and vegetation. In Vuilleumier, F., and Monasterio, M. (eds.), High altitude tropical biogeography. New York, Oxford: Oxford University Press, 153-200.

van Langevelde, F., van de Vijver, C., Kumar, L., van de Koppel, J., de Ridder, N., van Andel, J., Skidmore, A. K., Hearne, J. W., Stroosnijder, L., Bond, W. J., Prins, H. H. T., and Rietkerk, M., 2003: Effects of fire and herbivory on the stability of savanna ecosystems. Ecology, 84: 337-350.

Vilà, M., Lloret, F., Ogheri, E., and Terradas, J., 2001: Positive fire-grass feedback in Mediterranean Basin woodlands. Forest Ecology and Management, 147: 3-14.

Walter, H., and Medina, E., 1969: Die Bodentemperatur als ausschlaggebender Faktor für die Gliederung der subalpinen und alpinen Stufe in den Anden Venezuelas. Berichte Der Deutschen Botanischen Gesellschaft, 82: 275-281.

Wardle, P., 1965: A comparison of alpine timber lines in New Zealand and North America. New Zealand Journal of Botany, 3: $113-135$.

Wardle, P., Ezcurra, C., Ramirez, C., and Wagstaff, S., 2001: Comparison of the flora and vegetation of the southern Andes and New Zealand. New Zealand Journal of Botany, 39: 69-108.

Weberbauer, A., 1911: Die Pflanzenwelt der Peruanischen Anden in ihren Grundzügen dargestellt. Leipzig: Verlag von Wilhelm Engelmann. 
Wiegand, T., Camarero, J. J., Rüger, N., and Gutiérrez, E., 2006: Abrupt population changes in treeline ecotones along smooth gradients. Journal of Ecology, 94: 880-892.

Wille, M., Hooghiemstra, H., Hofstede, R., Fehse, J., and Sevink, J., 2002: Upper forest line reconstruction in a deforested area in northern Ecuador based on pollen and vegetation analysis. Journal of Tropical Ecology, 18: 409-440.

Wilson, J. B., and Agnew, A. D. Q., 1992: Positive-feedback switches in plant communities. Advances in Ecological Research, 23: $263-336$.

Winiger, M., 1979: Soil temperatures and precipitation as indicators of a climate-ecological classification in tropical high mountains [Bodentemperaturen und Niederschlag als Indikatoren einer klimatiscch-ökologischen Gleiderung tropischer Gebirgsräume]. Geomethodica, Veroffentlichungen des Basler Geomethodischen Colloquiums, 4: 121-150.

Young, K. R., and Keating, P. L., 2001: Remnant forests of Volcan Cotacachi, northern Ecuador. Arctic, Antarctic, and Alpine Research, 33: 165-172. 